\title{
10. ICE-RAFTED DEBRIS IN SEDIMENTS FROM LEG 71, SOUTHWEST ATLANTIC OCEAN ${ }^{1}$
}

\author{
Brian D. Bornhold, Geological Survey of Canada, Pacific Geoscience Centre, \\ Sidney, British Columbia, Canada
}

\begin{abstract}
The surficial few meters of sediment at Sites 511 and 512 on Maurice Ewing Bank consist of a lag deposit of icerafted sands and gravels ranging from lower Pliocene to Quaternary in age. The sediments contain up to $62 \%$ angular to subangular gravel of mixed lithology.

Significant volumes of sand- and gravel-sized ice-rafted detritus (IRD) first reached the Falkland (Malvinas) Plateau and southeasternmost Argentine Basin in the late Miocene $(6.9 \mathrm{Ma})$ in response to the rapid buildup and grounding of the ice sheet in West Antarctica. IRD accumulation rates remained relatively low until $4.15 \mathrm{Ma}$, after which they increased markedly. Peaks of IRD accumulation at Sites 513 and 514 can, in most instances, be correlated directly with colder climates in Antarctica and southern Patagonia.
\end{abstract}

\section{INTRODUCTION}

Undoubtedly the most graphic evidence of severe climatic change in high latitude sediments is the variation in concentration of ice-rafted sands and gravels (IRD). Bramlette and Bradley (1941) were the first to recognize the utility of these fluctuations in the identification of glacial and interglacial phases in the North Atlantic, and numerous studies have since been undertaken in the North Pacific (e.g., Kent et al., 1971), the North Atlantic (e.g., Ruddiman and McIntyre, 1976), and the Southern Ocean (e.g., Warnke, 1970; Margolis and Kennett, 1971; Kennett and Brunner, 1973; Blank and Margolis, 1975; Keany et al., 1976; Fillon, 1977) in an effort to establish the time of initiation of ice-rafting, its relationship to continental glaciation, and the association between IRD and paleoclimatic and paleoceanographic conditions.

The purposes of this paper are to (1) describe the fluctuations in concentration and composition of IRD from the Miocene to Quaternary in sediments obtained during Leg 71 (Fig. 1) and (2) to attempt to relate these observations to other records of subantarctic IRD accumulation and the late Cenozoic climatic history of the region.

Although icebergs transport virtually all sizes of sediment, most studies have used only the concentration of the sand fraction as an index of the intensity of icerafting. The difficulties of differentiating muds of icerafted origin from those of other sources and the ease of redistributing such sediments by surface and deep currents make it impractical to include them in estimates of ice-rafted debris. Despite this general agreement among various workers, ice-rafted detritus has been expressed in a great many ways, including concentration (percent or $\mathrm{mg} / \mathrm{g}$ dry wt.) for $>250 \mu \mathrm{m}, 62.5 \mu \mathrm{m}, 88 \mu \mathrm{m}$, and 62.5 to $250 \mu \mathrm{m}$; quartz sand grain abundance (grains/ $\mathrm{g}$; grains/sample); terrigenous sand grain abundance

\footnotetext{
${ }^{1}$ Ludwig, W. J., Krasheninnikov, V. A., et al. Init. Repts. DSDP, 71: Washington (U.S. Govt. Printing Office).
}

(grains/g); and apparent accumulation rate of $>88 \mu \mathrm{m}$, $>62.5 \mu \mathrm{m}$, or 62.5 to $250 \mu \mathrm{m}$ size material $\left(\mathrm{mg} / \mathrm{cm}^{2} / 1000\right.$ y. or quartz grains $/ \mathrm{cm}^{2} / 1000$ y.). In this study, IRD, both $>250 \mu \mathrm{m}$ and 62.5 to $250 \mu \mathrm{m}$, was determined as concentrations ( $\mathrm{mg} / \mathrm{g}$ total dry weight of sediment) and as apparent accumulation rates $\left(\mathrm{mg} / \mathrm{cm}^{2} / 1000 \mathrm{y}\right.$.) for the $>62.5 \mu \mathrm{m}$ fraction. The latter has been used commonly and is potentially the more useful measure for studies of rate changes through time and for comparison with other areas. Some caution, however, must be exercised in interpreting the accumulation rate results; the calculation assumes a constant sedimentation rate between stratigraphic datum levels, which, in this study, may be commonly more than 10 meters and several hundred thousand years apart. Significant undetected fluctuations in sedimentation rate, owing to changes in rate of delivery or in current velocity, will greatly affect the computed apparent IRD accumulation rates. Sites 511 and 512, on Maurice Ewing Bank, lie within the influence of the Antarctic Circumpolar Current (ACC), which has controlled to a great extent the deposition of sediment in the region (Ciesielski et al., 1982). Sites 513 and 514 , on the western flank of the Mid-Atlantic Ridge, lie in the path of Antarctic Bottom Water (AABW), the fluctuations of which have at times led to erosion or nondeposition in many areas of the Southern Ocean (e.g., Kennett and Watkins, 1976; Huang and Watkins, 1977; Ledbetter and Ciesielski, in press).

Terrigenous sands can reach the deep sea in several ways, including wind, turbidity currents, bottom currents, and icebergs. In most previous investigations (e.g., Margolis and Kennett, 1971) an eolian source has been generally discounted since most of the material is much too coarse to have been transported very far by winds. Many previous investigations have attempted to discriminate (using scanning electron microscopy) grains of primary glacial origin from those of other sources or those which had undergone extensive transport and reworking by seafloor currents. This technique was not felt to be warranted in this study for the following reasons: (1) Turbidites were not noted in sediments from 


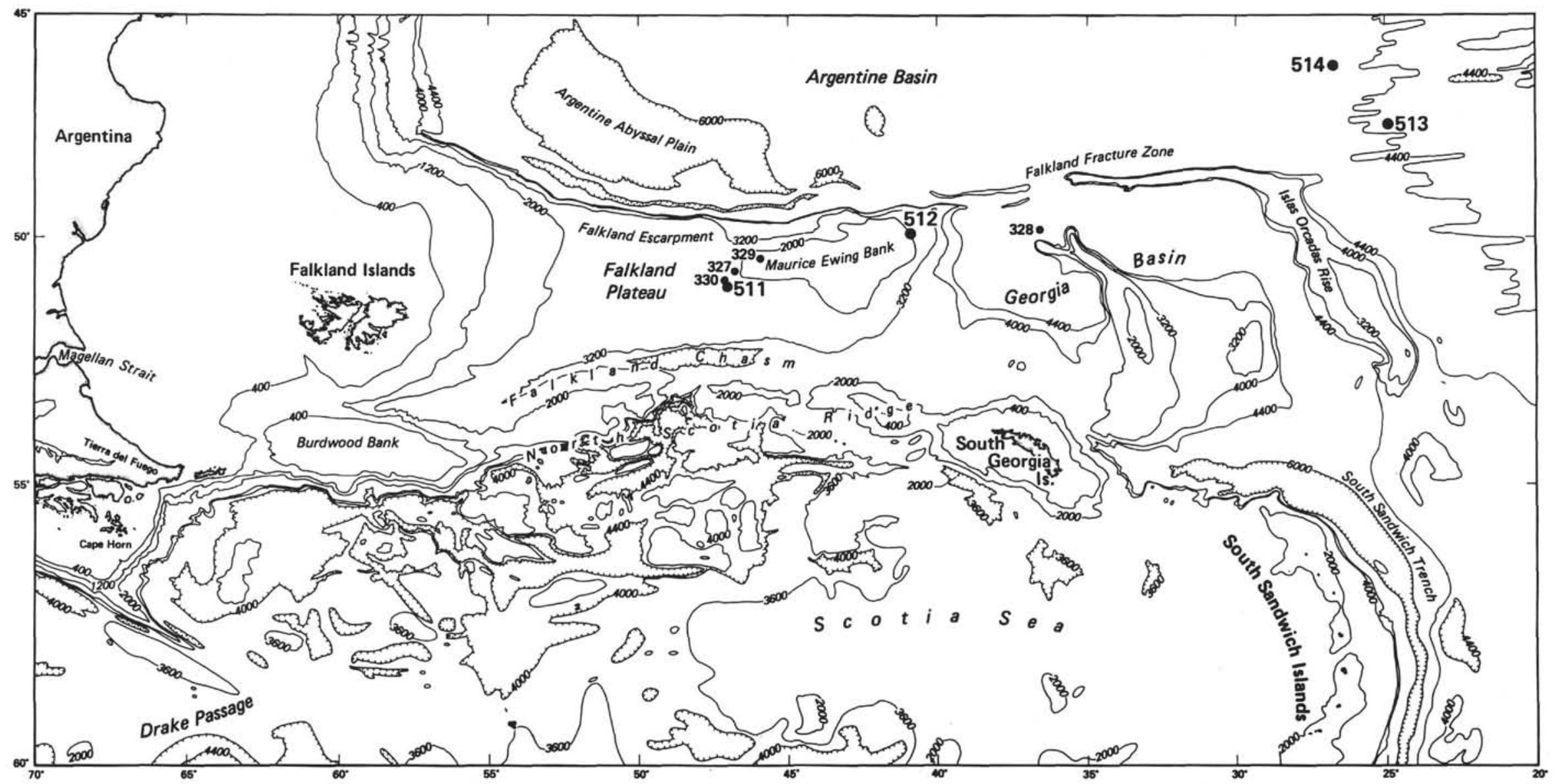

Figure 1. Site location map. 
Sites 513 and 514, which are located more than 1000 meters above the floor of the Argentine Abyssal Plain on the flank of the Mid-Atlantic Ridge; (2) extensive transport of sand by bottom currents at these sites seems unlikely, since accumulation of fine-grained sediments appears to have been continuous during the late Cenozoic, except for a few major erosional phases (Ludwig et al., $1980)$; (3) although the sandy sediments on Maurice Ewing Bank (Sites 511 and 512) have undoubtedly been redistributed by bottom currents to some extent, the isolation of the area virtually excludes all but an icerafting origin (Plafker et al., 1977; Ciesielski et al., 1982). Thus, in this study all terrigenous sands and gravels are assumed to have originated by ice-rafting, although it is recognized that at times some of the sediment may have undergone transport by bottom currents subsequent to deposition.

\section{METHODS}

Samples of $20 \mathrm{cc}$, taken every 100 to $150 \mathrm{~cm}$, were freeze-dried, weighed, and washed through a $62.5-\mu \mathrm{m}$ sieve. The sand fraction was dried, weighed, and split into a 62.5 to $250 \mu \mathrm{m}$ fraction and a $>250$ $\mu \mathrm{m}$ fraction. Sands from Sites 511 and 512 were sieved at 0.5 phi intervals, and the gravel fractions ( $>2 \mathrm{~mm}$ ) were weighed and described.

The finer-sized material consisted predominantly of diatoms and radiolarians. In order to remove as much biogenic material as possible and to facilitate the study of the IRD, this material was (1) placed in concentrated $\mathrm{HCl}$ for $1 \mathrm{hr}$; (2) sonified, using an ultrasonic probe, for 2 min.; and, (3) placed in Teflon digestion bombs and heated at $90-100^{\circ} \mathrm{C}$ in $2 \mathrm{M} \mathrm{Na}_{2} \mathrm{CO}_{3}$ for $24 \mathrm{hr}$. The residue was washed through a $62.5-\mu \mathrm{m}$ sieve, dried, and reweighed. Virtually all diatoms and manganese micronodules were destroyed by this procedure, but the more robust radiolarians remained. The ratio of biogenic to terrigenous material remaining was determined by grain counts of representative subsamples and used in calculating final weight of terrigenous sand between 62.5 and $250 \mu \mathrm{m}$ in size. The $>250 \mu \mathrm{m}$ fraction was examined under a binocular microscope and the terrigenous components identified and counted.

\section{RESULTS}

\section{Sediment Description}

\section{Sites 511 and 512}

The top 3 meters at Site 511 on the western flank of Maurice Ewing Bank consist of lower Pliocene to Quaternary siliceous, gravelly, medium sands and foraminiferal oozes, with abundant manganese nodules (Fig. $2 \mathrm{~A}-\mathrm{D})$. The sediments range from 14 to $49 \%$ angular to subangular gravel 0.5 to $1 \mathrm{~cm}$ in diameter, with rare clasts up to $2.5 \mathrm{~cm}$. In all six samples analyzed from this site, the median sand size was between 250 and $350 \mu \mathrm{m}$ (Fig. 3).

At Site 512, a 0.93-meter surficial unit similar to that at 511 was sampled. The sediments consist of olive gray, gravelly quartzose sands from early Pliocene to Quaternary in age (Fig. 2E, F). Gravel contents from three samples range from 0 to $62 \%$; the median sand size was between 125 and $177 \mu \mathrm{m}$ for two of the samples but was between 500 and $1410 \mu \mathrm{m}$ for the sample containing the greatest concentration of gravel (Fig. 4). The best-sorted sands are from the sample that contained no gravel.

Pebble lithologies at the two sites are similar to those described by Plafker et al. (1977) and include shale, mudstone, sandstone, basalt, granite, granodiorite, me- tavolcanics, quartz, and pumice in addition to manganese nodules. At Site 511, granitic, volcanic, metamorphic, and sandstone clasts are dominant, but the interval 511-1-1, 100-150 cm was significantly different, containing about $50 \%$ shale and mudstone.

\section{Sites 513 and 514}

Ice-rafted debris from these sites on the western flank of the Mid-Atlantic Ridge generally consists of disseminated fine to coarse sand with occasional granules and pebbles. Maximum sand size is about $500 \mu \mathrm{m}$, and the median grain size is usually between 150 and $250 \mu \mathrm{m}$. The sand is composed primarily of angular quartz with minor amounts of rounded, frosted quartz, feldspar, rock fragments, and accessory minerals (Table 1). IRD from 59 meters at Site 514 is noteworthy in that the sand contains a greater abundance of rock fragments $(48 \%)$ than quartz (44\%); associated with this material are shale and metamorphic and plutonic lithoclasts up to 6 $\mathrm{mm}$ in size.

Pebble-sized dropstones are well rounded to highly angular, range up to $8 \mathrm{~cm}$ in size, and are more abundant throughout the sedimentary section at Site 513 than at Site 514. Pebbles include graywackes, slates, basalts, metasediments, and granites.

\section{Variations in IRD Concentrations}

\section{Site 513}

The first appearance of dropstones and coarse sandsized quartz is at a depth of 152 to 153 meters $(6.9 \mathrm{Ma})$. The pebbles consist of two subangular sandstone clasts, the larger being $2 \times 3 \times 8 \mathrm{~cm}$ in size. Sand contents are relatively low at this depth and first increase significantly in the section between 131 and 118 meters (6.7$6.58 \mathrm{Ma}$ ) (Fig. 5, Interval 1). Accumulation rates average about $14 \mathrm{mg} / \mathrm{cm}^{2} / 1000 \mathrm{y}$. in comparison to the sections above (108-118 m) and below (133-170 m), which average less than $1 \mathrm{mg} / \mathrm{cm}^{2} / 1000 \mathrm{y}$. A slate lithoclast was found within this zone at 122.4 meters depth.

IRD concentrations and rates of accumulation, though highly variable, in general increase substantially above 110 meters. A major peak (Fig. 5, Interval 2) occurs at 106.5 meters $(5.46 \mathrm{Ma})$. The coarse quartz grain concentration ( 31 grains $/ g$ ) at this depth is more than 10 times higher than the maximum values in the earlier peak at 118 meters ( 2 grains/g). A similar IRD peak (Interval 3) at 86 meters (4.58 Ma) and a well-rounded dropstone ( $\sim 2 \mathrm{~cm}$; Fig. 6$)$ at 84.67 meters occur within a zone which, from smear slide descriptions, contains from 10 to $15 \%$ quartz, the highest recorded for Site 513.

A long interval of elevated concentrations and accumulation rates (Interval 4) extends from 76 meters $(4.1 \mathrm{Ma})$ to the hiatus at 56 meters $(3.86 \mathrm{Ma})$ and contains a zone of apparently in situ gravel consisting of subangular to subrounded graywacke and slate lithoclasts in the interval between 59.23 and 59.3 meters.

Ice-rafted debris reaches greatest concentrations above the 3.05 to $3.86 \mathrm{~m}$.y. hiatus. A broad peak (Interval 5), defined by six samples, extends from 47 to 38 meters (2.2- 


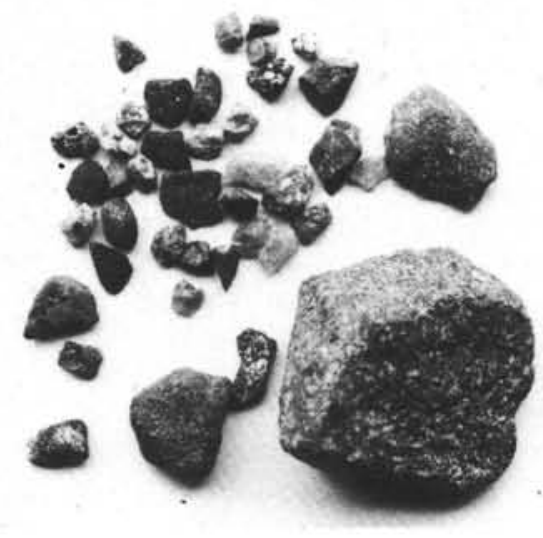

A

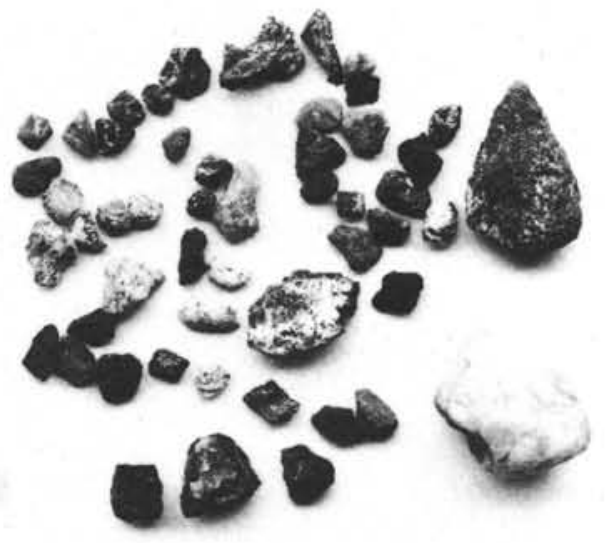

C

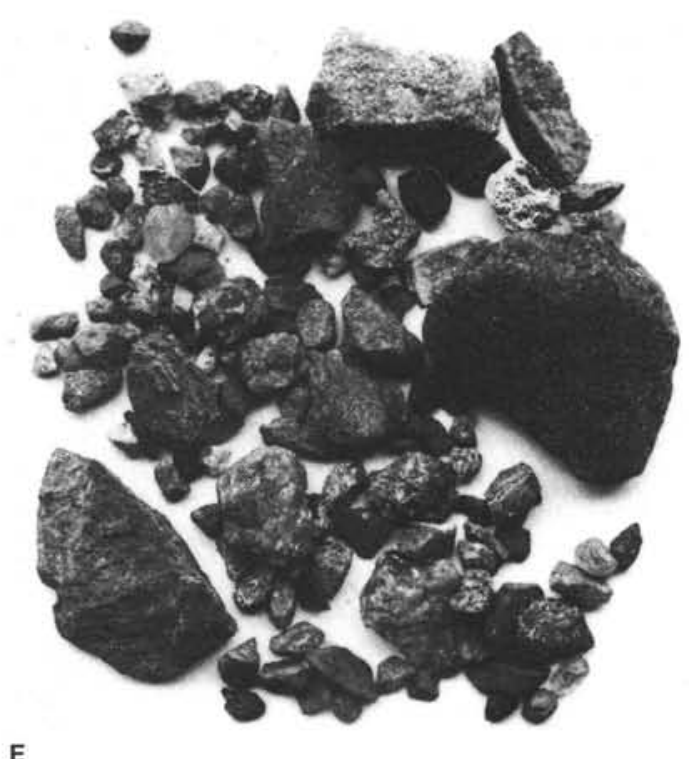

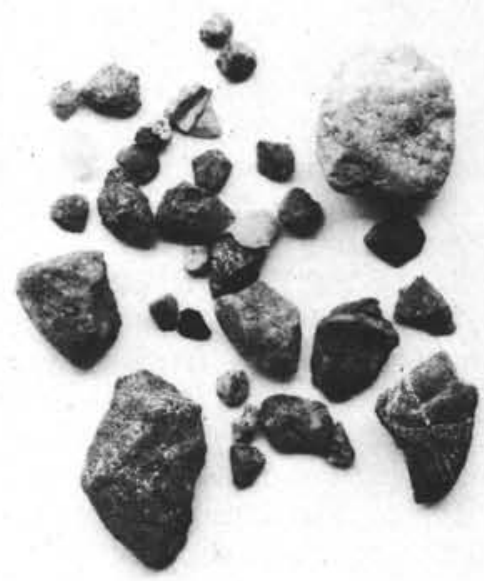

B

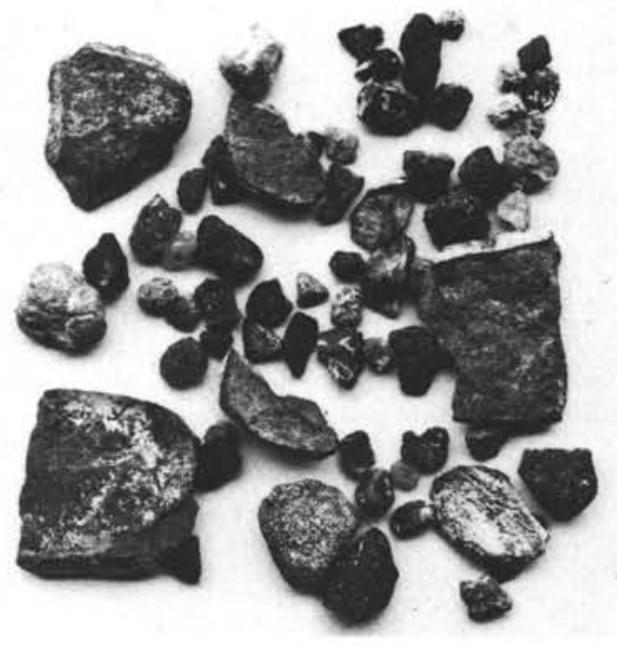

D

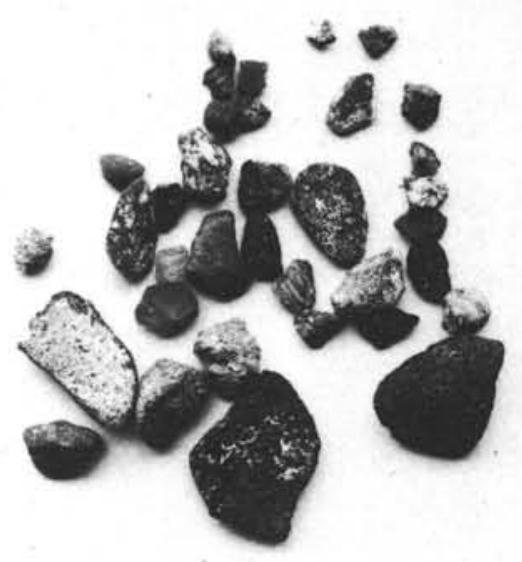

$\mathbf{F}$

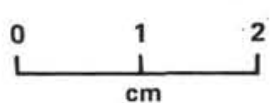

Figure 2. Ice-rafted gravels from Sites 511 and 512 on Maurice Ewing Bank. A. 511-1-1, 5-9 cm. B. 511-1-1, 20-24 cm. C. 511-1-1, 100-104 cm. D. 511-1-1, 146-150 cm. E. 512-1-1, 50-54 cm. F. 512-1-1, 75-79 cm. 

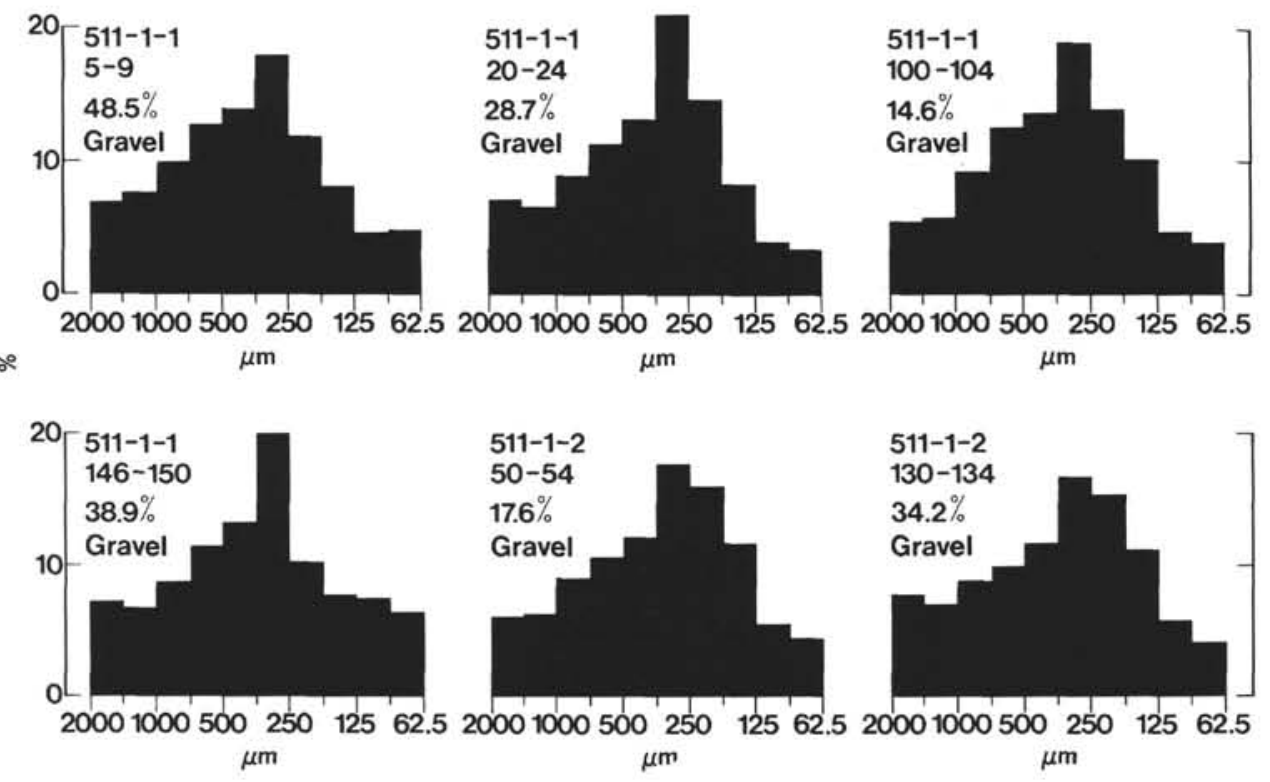

Figure 3. Grain size histograms for ice-rafted sediments at Site 511.

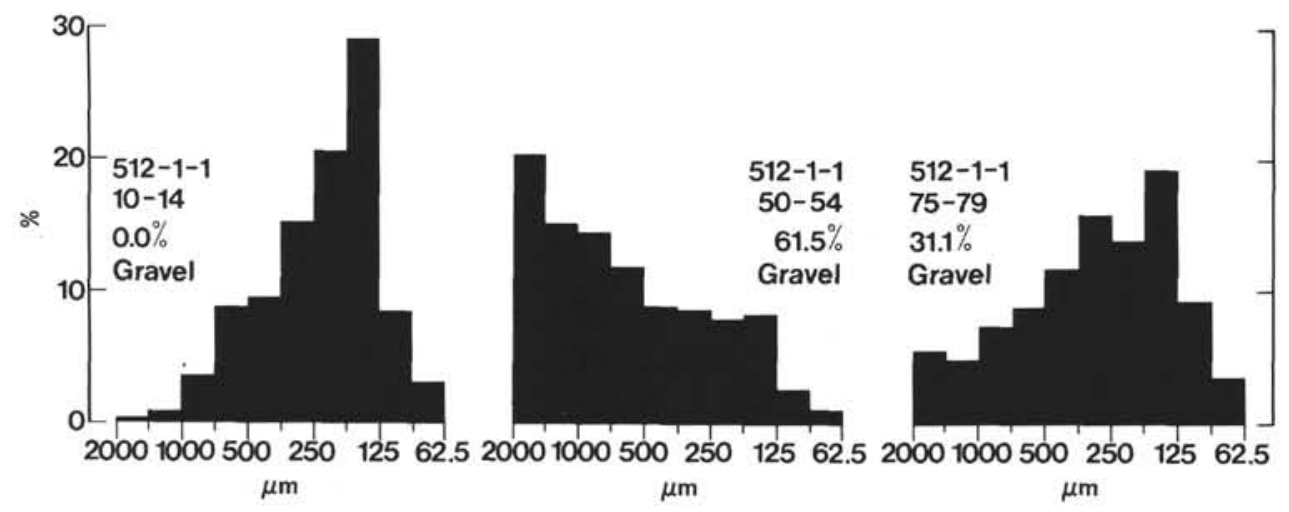

Figure 4. Grain size histograms for ice-rafted sediments at Site 512.

Table 1. Composition of ice-rafted debris $(>250 \mu \mathrm{m})$ and quartz grain $(>250 \mu \mathrm{m})$ concentration (grains/g total dry wt. of sample) for Sites 513 and 514 .

\begin{tabular}{|c|c|c|c|c|c|c|c|c|}
\hline \multirow[b]{2}{*}{ Hole } & \multirow[b]{2}{*}{ Peak $^{a}$} & \multirow{2}{*}{$\begin{array}{c}\text { Depth } \\
\text { below Seafloor } \\
\text { (m) }\end{array}$} & \multirow{2}{*}{$\begin{array}{c}\text { Sample } \\
\text { (interval in } \mathrm{cm} \text { ) }\end{array}$} & Quartz & $\begin{array}{c}\text { Rock } \\
\text { Fragments }\end{array}$ & Feldspar & Accessory & \multirow{2}{*}{$\begin{array}{c}\text { Quartz Grain } \\
\text { Abundance } \\
\text { (grains } / \mathrm{g} \text { ) }\end{array}$} \\
\hline & & & & & & $\%$ & & \\
\hline \multirow[t]{4}{*}{$513 \mathrm{~A}$} & 1 & 118.4 & $6-4,40-42$ & 74 & 21 & - & 5 & 2 \\
\hline & 2 & 106.4 & $5-2,90-92$ & 55 & 36 & 5 & 4 & 31 \\
\hline & 3 & 85.9 & $3-1,90-92$ & 69 & 24 & 3 & 4 & 7 \\
\hline & 4 & 72.8 & $2-5,80-82$ & 86 & 8 & 5 & 1 & 35 \\
\hline \multirow[t]{3}{*}{513} & 5 & 43.4 & $5-4,126-128$ & 67 & 24 & 6 & 3 & 148 \\
\hline & 6 & 21.8 & $3-3,25-27$ & 83 & 10 & 5 & 2 & 109 \\
\hline & 7 & 1.18 & $1-1,118-122$ & 84 & 9 & 5 & 2 & 88 \\
\hline \multirow[t]{6}{*}{514} & 1 & 138.2 & $33-1,60-62$ & 64 & 25 & 7 & 4 & 20 \\
\hline & 2 & 129.0 & $31-1,20-22$ & 77 & 17 & 6 & - & 4 \\
\hline & 3 & 77.3 & $19-1,17-19$ & 67 & 28 & 5 & - & 1 \\
\hline & 4 & 59.2 & $15-1,84-86$ & 44 & 48 & 6 & 2 & 97 \\
\hline & 5 & 32.5 & $9-1,46-48$ & 74 & 14 & 8 & 4 & 21 \\
\hline & 6 & 12.3 & $4-2,80-82$ & 85 & 10 & 4 & 1 & $\sim 1300$ \\
\hline
\end{tabular}

a See Figures 5 and 7. 


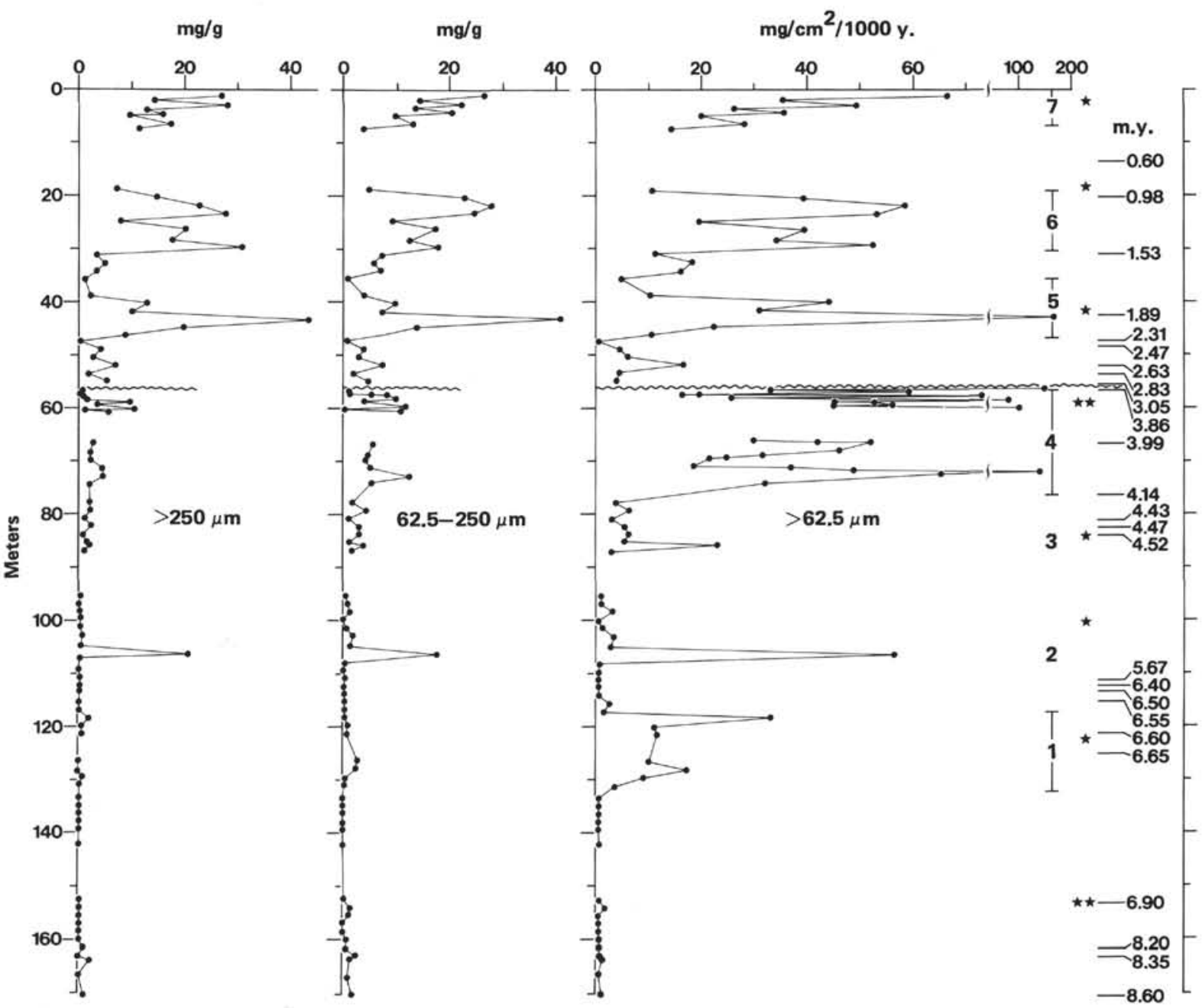

Figure 5. Variations in IRD concentration and apparent accumulation rate during the past $8.6 \mathrm{~m} . \mathrm{y}$. at Site 513 . Stratigraphic control is shown at the right (m.k.) adjacent to numbered intervals referred to in text. Asterisks represent pebble dropstones.

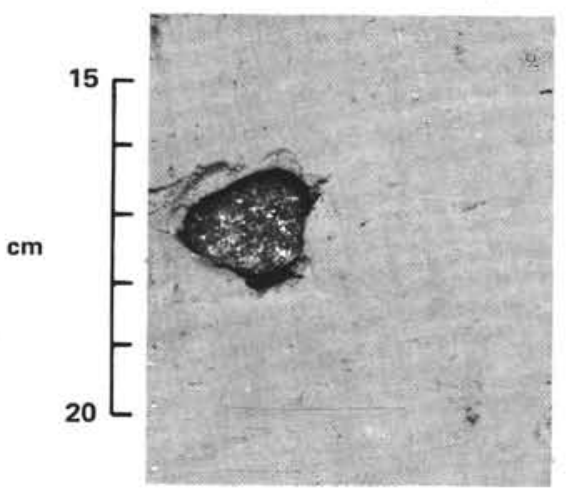

Figure 6. A well-rounded pebble dropstone $(513-9-7,17 \mathrm{~cm})$ at a depth of 84.67 meters $(4.53 \mathrm{Ma})$.

$1.75 \mathrm{Ma})$, culminating in a maximum accumulation rate of $160 \mathrm{mg} / \mathrm{cm}^{2} / 1000 \mathrm{y}$. at 43.4 meters $(1.93 \mathrm{Ma})$. A subangular basalt lithoclast $(4 \mathrm{~cm})$ was found at $42.35 \mathrm{me}$ ters depth.

A section of moderately high IRD concentrations (Interval 6) between 20 and 30 meters $(0.95-1.5 \mathrm{Ma})$ is divided into two prominent peaks at 22 and 29.5 meters.
Maximum accumulation rates in this section are between 55 and $60 \mathrm{mg} / \mathrm{cm}^{2} / 1000 \mathrm{y}$. Concentrations again increase (Interval 7) from 7.5 meters to the top of the hole ( $\sim 0.4 \mathrm{Ma}$ to present), reaching concentrations of $25-30 \mathrm{mg} / \mathrm{g}$ and rates of accumulation of $65-70 \mathrm{mg} /$ $\mathrm{cm}^{2} / 1000 \mathrm{y}$.

\section{Site 514}

Site 514 was cored to a depth of 150.8 meters into lower Pliocene sediments (4.06 Ma). IRD was present throughout this interval but was most abundant in the upper 70 to 80 meters. Pebbles were found only in the upper 10 meters ( $0.8 \mathrm{Ma}$ to present), unlike Site 513 , where they were found as early as $6.9 \mathrm{Ma}$.

Six zones of higher IRD abundance were identified by peaks of IRD concentration and high apparent accumulation rate (Fig. 6; Table 1). The first of these peaks (Fig. 7, Interval 1) lies between 143 and 134 meters $(4.03-3.99 \mathrm{Ma})$, reaching a maximum accumulation rate of $400 \mathrm{mg} / \mathrm{cm}^{2} / 1000$ y., the highest calculated for this site.

Two smaller peaks at 129 to 124 meters (3.97-3.94 $\mathrm{Ma}$; Interval 2) and 83 to $75 \mathrm{~m}$ (2.86 to $2.79 \mathrm{Ma}$; Interval 3) are followed by a major zone (Interval 4) of very 


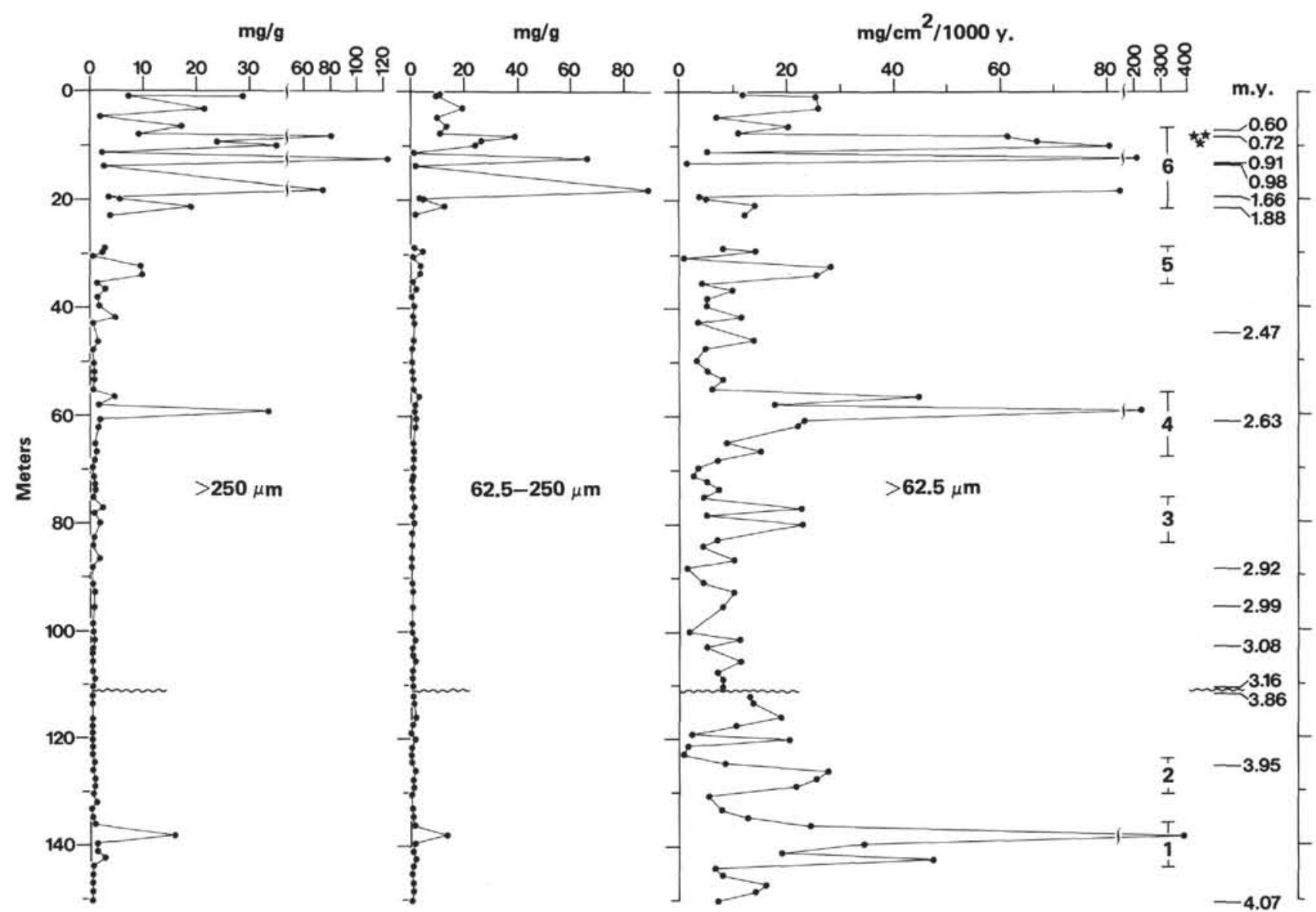

Figure 7. Variations in IRD concentration and apparent accumulation rate during the past 4.07 m.y. at Site 514 . Stratigraphic control is shown at the right (m.y.) adjacent to Intervals (1-6) referred to in text. Asterisks represent pebble dropstones.

high levels between 68 and 56 meters $(2.69-2.58 \mathrm{Ma})$. Average IRD accumulation rates in Interval 4 are 65 $\mathrm{mg} / \mathrm{cm}^{2} / 100 \mathrm{y}$, with a maximum value of $215 \mathrm{mg} / \mathrm{cm}^{2} /$ $1000 \mathrm{y}$.

A zone (Interval 5) of high concentrations and accumulation rates occurs between 35 and 31 meters, followed by a long interval (6) from approximately 22 meters to the top of the hole (1.9 Ma to the present), exhibiting the highest concentrations and some of the highest accumulation rates encountered at this site. Though values are highly variable, several peaks occur with total IRD concentrations greater than $120 \mathrm{mg} / \mathrm{g}$ and accumulation rates as high as $200 \mathrm{mg} / \mathrm{cm}^{2} / 1000 \mathrm{y}$. Coarse quartz grain concentrations reach values in excess of 1000 grains $/ g$, the highest measured at either Site 513 or 514 (Table 1). Prominent, very sandy zones with angular granule-sized lithic fragments occur throughout this section between 7.6 and 6.9 meters, and angular granitic pebbles $(1-2 \mathrm{~cm})$ were found in association with layers rich in quartz sand at 8.10 and 9.23 meters.

\section{DISCUSSION}

\section{Sites 511 and 512}

The polymictic gravels of early Pliocene to Holocene age at these sites are lag deposits produced during periods of erosion on Maurice Ewing Bank by the Antarctic
Circumpolar Current (Ciesielski et al., 1982). According to these authors, after an intense erosional phase, which began in the late Miocene and lasted until the early Pliocene ( 7.2-4.7 Ma.), intermittent deposition resumed until $2.2 \mathrm{Ma}$, when currents again intensified, leading to a regional disconformity from 2.0 to $1.0 \mathrm{Ma}$. Sedimentation was again intermittent from $0.7 \mathrm{Ma}$ to the present. Sediments deposited on the bank during intervals of lower current velocity were protected from subsequent erosion by the formation of a lag, or armor, of icerafted sands and gravels.

The presence of several disconformities during the short lower Miocene to Quaternary sections and the lack of adequate stratigraphic markers make it impossible to provide any accurate estimates of the rate of delivery of IRD to Maurice Ewing Bank. If it is assumed that bottom currents are incapable of transporting most of the sand- and gravel-sized IRD, then the average rate of accumulation over the past 7.6 m.y. (age of the first dropstones on Maurice Ewing Bank; Ciesielski et al., 1982) is approximately 25 to $35 \mathrm{mg} / \mathrm{cm}^{2} / 1000 \mathrm{y}$.- not unreasonable rates compared with Site 513 in the nearby Argentine Basin, which averages $24.5 \mathrm{mg} / \mathrm{cm}^{2} / 1000 \mathrm{y}$. for the last $7.5 \mathrm{~m} . \mathrm{y}$.

As Plafker et al. (1977) indicate, most of the lithologies are compatible with either a South American or an Antarctic origin. However, reddish brown arkosic 
sandstone clasts, similar to those described by Plafker et al. (1977), may be derived from the Beacon Supergroup in Antarctica. They make up 5 to $10 \%$ of the gravel fraction at Sites 511 and 512; no similar sandstones are known from southern South America.

\section{Sites 513 and 514}

Sites 513 and 514 together provide an excellent record of variations in IRD delivery to the southeasternmost Argentine Basin from about 8.6 Ma to the present. Because these sites are relatively close and only $150 \mathrm{~km}$ apart latitudinally, their apparent IRD accumulation rate curves have been combined and replotted against time (Fig. 8) to produce a generalized summary for the region.

The first occurrence of both pebble-sized IRD and a significant amount of sand-sized quartz was at about 6.9 to $7.0 \mathrm{Ma}$. (Site 513) shortly after the first dropstones were noted on Maurice Ewing Bank. This is considerably earlier than the first significant IRD reported at Site 328 in the nearby Malvinas Outer Basin ( 4.64.7 Ma; Ciesielski et al., 1982). The reason for the late appearance of IRD in the Malvinas Outer Basin is not clear, since Site 328 lies between Maurice Ewing Bank and Site 513.

Plafker et al. (1977) suggest that prior to the initiation of ice-rafting at 45 to $55^{\circ} \mathrm{S}$, the fine, sand-sized detritus in marine sediments was delivered by winds either directly to the sea or to seasonal pack ice which then rafted the grains to the Falkland (Malvinas) Plateau area. Ciesielski et al. (1982) argue that it was derived principally by ice-rafting in small bergs from outlet glaciers and small ice shelves in East Antarctica. Both studies conclude, however, that significant icerafting began only with the expansion and grounding of the West Antarctic ice sheet in the latest Miocene.

An interval of high accumulation rates of IRD at Site 513 (Fig. 8, Interval A) between 6.5 and 6.7 Ma falls within a major erosional phase on Maurice Ewing Bank which lasted from about 7.2 to $6.3 \mathrm{Ma}$. Thus the expansion of the West Antarctic ice sheet resulted not only in greater ice rafting but also in a more vigorous Antarctic Circumpolar Current circulation, which affected sedimentation on nearby banks.

A period of apparently reduced ice-rafting from about 6.5 to $5.5 \mathrm{Ma}$ was followed by slightly elevated levels from 5.5 to $5.0 \mathrm{Ma}$, reaching a peak at $5.46 \mathrm{Ma}$ (Fig. 8, Interval B). This interval of increased IRD lies within a period of general climatic cooling and glacial expansion which began about 6.0 Ma (Loutit and Kennett, 1979) and lasted until about 5.2 Ma. Dramatic glacio-eustatic sea level lowering of 40 to 100 meters reported in New Zealand (Kennett, 1965) and Spain (Berggren and Haq, 1976), the growth of Andean glaciers (Mercer, 1979), and the possible initiation of an erosional interval in the Ross Sea (Hayes, Frakes, et al., 1975) occurred during this time.

Both IRD concentrations and rates of accumulation are relatively low from 4.8 to $4.3 \mathrm{Ma}$, though not as low as in sediments older than $7.0 \mathrm{Ma}$. Markedly warmer climatic conditions in the early Pliocene have been pro-

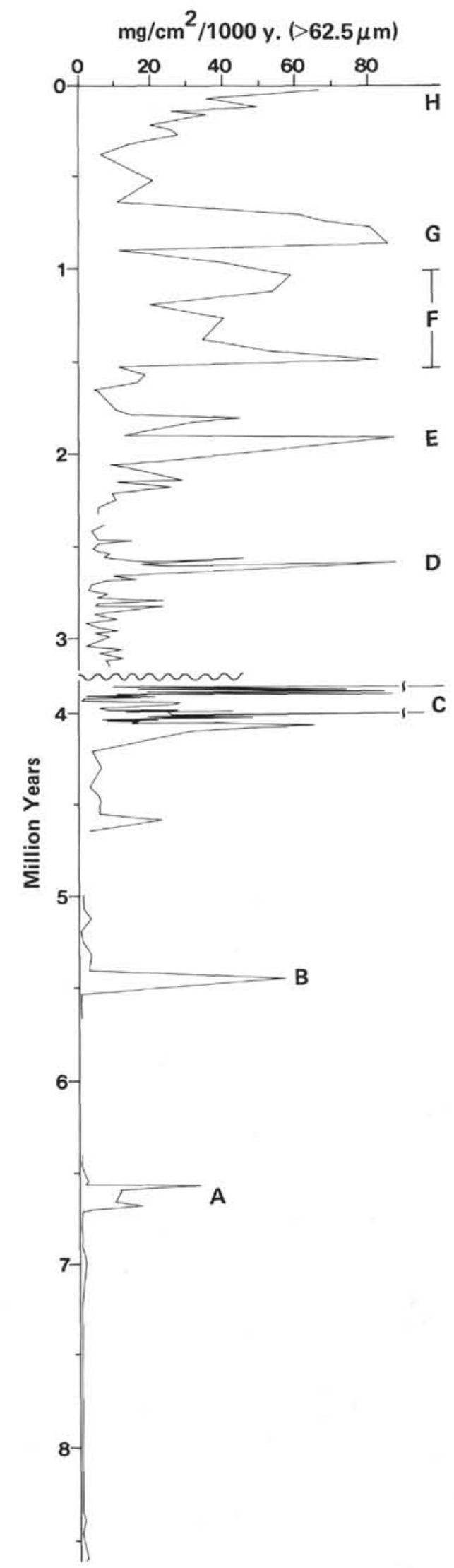

Figure 8. Generalized IRD apparent accumulation rate curve from the combined results of Sites 513 and 514. Intervals referred to in text are lettered at right $(\mathrm{A}-\mathrm{H})$. 
posed for this period by Hays and Opdyke (1967), Bandy et al. (1971), Ciesielski and Weaver (1974), and Weaver (1976), and continued ice-rafting may be due to the deterioration of the extensive West Antarctic ice sheet, undoubtedly accompanied by ungrounding and significant calving of sediment-laden ice-bergs. With sea surface temperatures 5 to $10^{\circ}$ warmer than today in the Southern Ocean (Ciesielski et al., 1982), icebergs would tend to deteriorate more rapidly, leading to higher rates of IRD accumulation but restricted to somewhat higher latitudes (Keany et al., 1976).

Between 4.1 and 3.86 Ma (Interval C) apparent accumulation rates are highly variable at both Sites 513 and 514 and reach maxima several times greater than any previous levels. The highest recorded accumulation rate for these sites was $400 \mathrm{mg} / \mathrm{cm}^{2} / 1000 \mathrm{y}$. at Site 514 at $4.01 \mathrm{Ma}$. This peak in IRD falls within a major cooling trend which began about $4.2 \mathrm{Ma}$ and continued until about 3.0 Ma, culminating in Antarctic conditions which, between 3.80 and $3.45 \mathrm{Ma}$, were more severe than at present (Weaver, 1973; Ciesielski and Weaver, 1974). This cooling was accompanied by a reestablishment of the West Antarctic ice sheet and a tremendous increase in transport of IRD to the southernmost Argentine Basin.

Higher velocities of Antarctic Bottom Water (AABW) accompanied this cooling and led to a major hiatus from 3.05 to $3.86 \mathrm{Ma}$ at Site 513 and 3.16 to $3.86 \mathrm{Ma}$ at Site 514. During this same interval the Antarctic Circumpolar Current (ACC) also intensified and resulted in two major erosional phases on Maurice Ewing Bank (Ciesielski et al., 1982). Much of the apparent variation in IRD accumulation rates in the Leg 71 sites can probably be accounted for by drastic fluctuations in overall sedimentation rates related to the varying intensity of AABW at this time.

IRD concentrations following this hiatus (3.1-2.7 Ma) are relatively low (Fig. 8), reflecting the generally warm conditions proposed for this period (Anderson, 1972; Ciesielski et al., 1982). Ciesielski et al. (1982) infer a change to increased ice-rafting and higher current velocities on Maurice Ewing Bank subsequent to $2.6 \mathrm{Ma}$. The record from Sites 513 and 514 is consistent with this interpretation, showing an interval of higher IRD between about 2.69 and $2.58 \mathrm{Ma}$ (Interval D) and reaching a maximum at 2.61 Ma. Most evidence from other sources suggests that the cool conditions which began at about 2.6 Ma continued until about 1.0 Ma (e.g. Anderson, 1972; Fillon, 1975; Keany and Kennett, 1972; Kennett and Watkins, 1976).

IRD accumulation is highly variable through this interval (2.6-1.0 Ma), with maxima between 2.1 and 1.8 (Interval $\mathrm{E}$ ) and between 1.5 and $0.97 \mathrm{Ma}$ (Interval $\mathrm{F}$ ), separated by rather low levels. This pattern may reflect trends in IRD predicted by the model of Keany et al. (1976), in which a sustained glacial interval would be marked at "intermediate latitudes" by peaks at the beginning and end of the cool period. Alternatively, there is some evidence, particularly from Patagonia, that the two later peaks coincide with much more severe climatic conditions. Several tills in Patagonia have been dated at
2.10 to $1.71 \mathrm{Ma}$, the thickest being between 2.10 and 1.91 m.y. old (Fleck et al., 1972, and Mercer (1976) has determined that the most severe glacial phase in Patagonia occurred 1.3 to $1.0 \mathrm{Ma}$.

Very high rates of IRD accumulation characterize the interval from 0.90 to $0.65 \mathrm{Ma}$. (G) at Site 514 (owing to poor recovery, sediments of this age were not cored at Site 513). A similar period of high IRD has been noted in studies from other areas (Keany et al., 1976; Ledbetter and Watkins, 1978) as well as from Maurice Ewing Bank (Ciesielski et al., 1982). This interval apparently does not correspond to deteriorating climatic conditions, however; according to Ciesielski et al. (1982), climatic conditions moderated somewhat about 1.0 Ma, leading to less vigorous ACC and renewed deposition on Maurice Ewing Bank. Thus this greater IRD contribution does not appear to be related to increased Antarctic glaciation but rather to changing circulation patterns and accelerated rates of melting of icebergs as they encountered warmer waters near $50^{\circ} \mathrm{S}$.

The last 400,000 years are characterized at Sites 513 and 514 by a "sawtooth" increase in rates of IRD accumulation (Fig. 8, Interval $\mathrm{H}$ ). Unfortunately, stratigraphic control is limited throughout this period, thus precluding correlation with paleoclimatic inferences in other studies.

\section{CONCLUSIONS}

The study of ice-rafted debris from Leg 71 sites confirms the findings of previous investigations in the area that significant amounts of IRD first reached as far north as the Falkland (Malvinas) Plateau and southernmost Argentine Basin in the late Miocene. IRD accumulation rates remained relatively low until $4.15 \mathrm{Ma}$, after which overall levels, though highly variable, increased markedly.

IRD concentrations and accumulation rates can in many instances be correlated directly with paleoclimatic events or episodes in Antarctica and the Southern Ocean region determined from other studies. Colder climates are generally associated with much higher IRD abundance. There is, however, some evidence to support the model proposed by Keany et al. (1976) for the diachronous deposition of IRD: higher accumulation rates during both cooling and warming periods with reduced levels at the height of the glacial or interglacial phase when the locus of maximum IRD accumulation is either north or south of the drilling site. Unfortunately, this model cannot be satisfactorily tested at the present time in this area because of lack of adequate stratigraphic control, sedimentation rate variations between stratigraphic datum levels, and undoubtedly significant changes in surface circulation patterns and iceberg drift tracks between glacial and interglacial periods.

\section{ACKNOWLEDGMENTS}

I would like to express my thanks to Elaine Goldstein, Christian Robert, John Usher, and Paul Ciesielski for helpful discussions both during and following Leg 71. L. Sarracino assisted with laboratory analyses, and W. Price and R. Franklin drafted the figures. Patrick McLaren and C. J. Yorath critically read the paper and made many valuable suggestions for its improvement. 


\section{NOTE ADDED IN PROOF}

The absolute ages and IRD accumulation rates calculated by Bornhold for the Miocene section of Hole 513A (Cores 513A-5 to 513A-11) are inaccurate because this manuscript was submitted before the final correlations of this section to the paleomagnetic time scale by Weaver (this volume) and Ciesielski (this volume). The constraints of the publication schedule made correction impossible. Revised ages of Hole 513 Miocene IRD peaks are given by Ciesielski and Weaver (this volume), who provide a thorough discussion of Leg 71 IRD occurrences and relationships to overall Southern Ocean ice-rafting.

\section{REFERENCES}

Anderson, J. B., 1972. The Marine Geology of the Weddell Sea. Florida State University Sedimentological Res. Lab., Contrib. 35.

Bandy, O. L., Casey, R. E., and Wright, R. C., 1971. Late Neogene planktonic zonation, magnetic reversals, and radiometric dates, Antarctic to the tropics. In Reid, J. L. (Ed.), Antarctic Oceanography 1. Am. Geophys. Union, Antarctic Research Series, 15, $1-26$.

Berggren, W. A., and Haq, B. U., 1976. The Andalusian Stage (Late Miocene): biostratigraphy, biochronology and paleoecology. Palaeogeogr., Palaeoclim., Palaeoecol., 20:67-129.

Blank, R. G., and Margolis, S. V., 1975. Pliocene climatic and glacial history of Antarctica as revealed by southeast Indian Ocean deepsea cores. Geol. Soc. Am. Bull., 86:1058-1066.

Bramlette, M. N., and Bradley, W. H., 1941. Geology and biology of North Atlantic deep-sea cores between Newfoundland and Ireland: lithology and geological interpretation. U.S. Geol. Surv. Prof. Paper 196-A, 1.

Ciesielski, P. F., Ledbetter, M. T., and Ellwood, B. B., 1982. The development of Antarctic glaciation and the Neogene paleoenvironment of the Maurice Ewing Bank. Mar. Geol. 46:1-51.

Ciesielski, P. F., and Weaver, F. M., 1974. Early Pliocene temperature changes in the Antarctic Seas. Geology, 2:511-515.

Fillon, R. H., 1975. Late Cenozoic paleo-oceanography of the Ross Sea, Antarctica. Geol. Soc. Am. Bull., 86:839-845.

1977. Ice-rafted detritus and paleotemperature: late Cenozoic relationships in the Ross Sea region. Mar. Geol., 25:73-93.

Fleck, R. J., Mercer, J. H., Nairn, A. E. M., and Peterson, D. N., 1972. Chronology of late Pliocene and early Pleistocene glacial and magnetic events in southern Argentina. Earth Planet. Sci. Lett., 16:15-22.

Hayes, D. E., Frakes, L. A., et al., 1975. Init. Repts. DSDP, 28: Washington (U.S. Govt. Printing Office).

Hays, J. D., and Opdyke, N. D., 1967. Antarctic radiolaria, magnetic reversals, and climate changes. Science, 158:1001-1011.

Huang, T. C., and Watkins, N. D., 1977. Contrasts between the Brunhes and Matuyama sedimentary records of bottom water activity in the South Pacific. Mar. Geol., 23:113-132.

Keany, J., and Kennett, J. P., 1972. Pliocene-early Pleistocene paleoclimatic history recorded in Antarctic-Subantarctic deep-sea cores. Deep Sea Res., 19:529-548.

Keany, J., Ledbetter, M. T., Watkins, N. D., and Huang, T. C., 1976. Diachronous deposition of ice-rafted debris in sub-Antarctic deep-sea sediments. Geol. Soc. Am. Bull., 84:2043-2053.
Kennett, J. P., 1965. Faunal succession in two upper Miocene-lower Pliocene sections, Marlborough, New Zealand. Trans. Roy. Soc., New Zealand, 3:197-213.

Kennett, J. P., and Brunner, C. A., 1973. Antarctic late Cenozoic glaciation: Evidence for initiation of ice rafting and inferred increased bottom-water activity. Geol. Soc. Am. Bull., 84:2043-2052.

Kennett, J. P., and Watkins, N. D., 1976. Regional deep-sea dynamic processes recorded by late Cenozoic sediments of the southwestern Indian Ocean. Geol. Soc. Am. Bull., 87:321-339.

Kent, D., Opdyke, N. D., and Ewing, M., 1971. Climate changes in the North Pacific using ice-rafted detritus as a climatic indicator. Geol. Soc. Am. Bull., 82:2741-2754.

Ledbetter, M. T., and Ciesielski, P. F., in press. Bottom current erosion in the South Atlantic sector of the Southern Ocean. Mar. Geol.

Ledbetter, M. T., and Watkins, N. D., 1978. Separation of primary ice-rafted debris from lag deposits, utilizing manganese micronodule accumulation rates in abyssal sediments of the Southern Ocean. Geol. Soc. Am. Bull., 89:1619-1629.

Loutit, T. S., and Kennett, J. P., 1979. Application of carbon isotope stratigraphy to late Miocene shallow marine sediments, New Zealand. Science, 204:1196-1199.

Ludwig, W. J., Krasheninnikov, V., Basov, I. A., Bayer, U., Bloemendal, J., Bornhold, B. D., Ciesielski, P. F., Goldstein, E. H., Robert, C., Salloway, J. C., Usher, J. L., von der Dick, H., Weaver, F. M., and Wise, S. W., Jr., 1980. Tertiary and Cretaceous paleoenvironments in the southwest Atlantic Ocean: Preliminary results of Deep Sea Drilling Project Leg 71. Geol. Soc. Am. Bull., 91:655-664.

Margolis, S. V., and Kennett, J. P., 1971. Cenozoic paleoglacial history of Antarctica recorded in sub-Antarctic deep-sea cores. Am. J. Sci., 271:1-36.

Mercer, J. H., 1976. Glacial history of southernmost South America. Quat. Res., 6:125-166.

1979. Late Miocene to earliest Pliocene glaciation in southern Argentina. Geol. Soc. Am., Abstr. with Programs, 11:478. (Abstract)

Plafker, G., Bartsch-Winkler, S., and Ovenshine, A. T., 1977. Paleoglacial implications of coarse detritus in DSDP Leg 36 cores. In Barker, P. F., Dalziel, I. W. D., et al., Init. Repts. DSDP, 36: Washington (U.S. Govt. Printing Office).

Ruddiman, W. F., and McIntyre, A., 1976. Northeast Atlantic paleoclimatic changes over the past 600,000 years. Geol. Soc. Am. Mem., 145:111-146.

Warnke, D. A., 1970. Glacial erosion, ice-rafting and glacial marine sediments: Antarctica and the Southern Ocean. Am. J. Sci., 269: 279-294.

Weaver, F. M., 1973. Pliocene Paleoclimatic and Paleoglacial History of East Antarctica Recorded in Deep-Sea Piston Cores. Florida State University, Sedimentological Res. Lab., Cont. 36.

1976. Late Miocene and Pliocene radiolarian paleobiogeography and biostratigraphy of the Southern Ocean [Ph.D. dissert.]. Florida State University, Tallahassee. 